\title{
O CORPO RACIALIZADO NOS MUROS DA CIDADE: IMAGEM E DECOLONIALIDADE NAS INTERVENÇÕES URBANAS DE ÉDER OLIVEIRA
}

\author{
Maria Cristina Simões Viviani ${ }^{1}$ \\ Rômulo Fonseca Morais ${ }^{2}$
}

\section{Introdução}

Expor a arte é exibir fatos à consciência e romper a opacidade política dos vencidos da história.

Paulo Herkenhoff

Para quem se depara com o trabalho de Éder Oliveira nos muros da cidade de Belém pode não perceber a origem daqueles rostos, retratados em dimensões maiores que as naturais, com cores vibrantes e monocromáticas. O paraense natural do vilarejo de Velha Timboteua, nascido em 1983, define-se enquanto mestiço, com raízes negras, indígenas e brancas. De família humilde, mudou-se para a cidade de Belém aos 18 anos de idade para realizar a graduação em Educação Artística pela Universidade Federal do Pará. O artista contemporâneo realiza uma releitura de fotografias encontradas nos jornais paraenses feitas, na maioria das vezes, em delegacias da região. Essas fotos, produzidas em tom de acusação e denúncia de possíveis delitos, são o ponto de partida da obra de Oliveira, que também as utiliza para denunciar problemas sociais, mas sob outro prisma.

Se primeiramente aqueles semblantes são publicados no caderno policial para supostamente trazer informações sobre as questões relacionadas à violência urbana e à segurança pública, eles paradoxalmente retornam ao jornal no caderno cultural pelo trabalho de Oliveira, trazendo à tona um processo de exclusão social e violência estrutural que atingem esses corpos. O artista nos instiga a questionar o porquê daquele padrão de corpos estarem diariamente sendo enquadrados como perigosos e responsáveis pelos males sociais do contexto brasileiro.

\footnotetext{
${ }^{1}$ Universidade Federal do Pará, Brasil. Email: cris.vivi@hotmail.com ORCID id: https://orcid.org/0000-0001-8009-8199

${ }^{2}$ Universidade do Estado do Rio de Janeiro, Brasil. Email: romulofmmiri@hotmail.com ORCID iD: https://orcid.org/0000-0001-9154-0974
} 
Naturalizamos e nos acostumamos com estes corpos (negros, indígenas, caboclos etc.,) sendo representados frequentemente na mídia como portadores de perigos e inseguranças sociais. É por isso que muitas vezes nos causa estranhamento a quebra deste estereótipo quando estes corpos passam a ocupar posições ou lugares de destaque na estrutural social e na paisagem estética hegemônica, ou, então, quando outros corpos, geralmente brancos e a priori não estigmatizados, passam a ocupar o lugar do sujeito perigoso. O seletivo sistema de justiça criminal brasileiro estruturado no racismo ${ }^{3}$, e direcionado ao controle e aprisionamento de corpos negros e indígenas, forja imageticamente o estereótipo e o perfil dos sujeitos perigosos, lançando uma penumbra sobre as complexas e singulares histórias de vida dessas pessoas, ou seja, uma típica prática de desumanização que tem como consequência a legitimação de uma série de práticas violentas sobre esses corpos. Submetidos a diversas práticas de punição e controle social violento, como a prisão e a morte, permanece historicamente sobre esses indivíduos de pele escura uma implacável estratégia colonial de domesticação e apagamento, resplandecendo o que, a partir de Frantz Fanon $^{4}$, trataremos como Corpo Racializado.

O número de jovens negros assassinados são destaque no Brasil. Frequentemente as estatísticas e análises sobre morte violenta demonstram o massacre que atinge a juventude negra. Os dados do Mapa da Violência (2014 - Os jovens no Brasil) mostram que 556 mil cidadãos foram vítimas de homicídio no Brasil entre 2002 e 2012, desse total mais de 303 mil eram jovens e mais de 215 mil eram jovens negros. A taxa de homicídios de jovens chegou a 53,3\% do total de homicídios do país em 2018 (30.873 jovens na faixa etária entre 15 e 29 anos foram mortos naquele ano), segundo levantamento mais recente do Atlas da

\footnotetext{
${ }^{3}$ Sobre a seletividade e o racismo estrutural do sistema penal brasileiro, que desembocam em práticas de controle social genocidas, trabalhamos com: MORAIS, Rômulo. O extermínio da juventude negra: uma análise sobre os discursos que matam. Rio de Janeiro: Revan, 2019. FLAUZINA, Ana Luiza Pinheiro. Corpo negro caído no chão: o sistema penal e o projeto genocida do Estado brasileiro. Dissertação (Mestrado em Direito) - Universidade de Brasília, Brasília, 2006.

${ }^{4}$ A expressão corpo racializado é aqui retomada a partir das análises de Frantz Fanon. Ou seja, um corpo decorrente ou que vai se constituir a partir das violentas relações coloniais, numa perspectiva subalternizada e estigmatizada pelos aspectos mais negativos e desumanos, que chegam ao ponto de negação das características e aspectos desse corpo negro: "no mundo branco, o homem de cor encontra dificuldades na elaboração de seu esquema corporal. O conhecimento do corpo é unicamente uma atividade de negação." Todavia, buscamos com essa análise deslocar nosso olhar desse corpo colonial para um corpo decolonial, em que a arte de Éder Oliveira se torna fundamental para a ressignificação e reconstrução desses corpos e suas multiplicidade de formas de driblar os padrões hegemônicos de ser e estar no mundo. Ver: FANON, F. Pele negra, máscaras brancas. Salvador: EDUFBA, 2008.
} 
Violência 2020 realizado pelo Instituto de Pesquisa Econômica Aplicada (IPEA).

O recorte étnico/racial é ainda mais assustador. Os dados do Mapa da Violência demonstram que em 2002 morreram proporcionalmente 73\% mais negros que brancos. Em 2012, esse índice sobe para 146,5. A vitimização negra, no período de 2002 a 2012, cresceu significativamente: 100,7\%, mais que duplicou. ${ }^{5}$ O Atlas da Violência de 2020 publicado pelo IPEA aponta que para cada pessoa não negra assassinada em 2018, 2,7 negros foram mortos, sendo estes $75,7 \%$ das vítimas. Outro dado que reforça o racismo é o fato de a taxa de homicídios entre negros chegar a 37,8 a cada 100 mil habitantes, enquanto entre não negros esse número é de 13,9 para cada 100 mil habitantes

Em um intervalo de 10 anos (2002 a 2012) foram assassinados mais de 5 mil jovens entre 15 e 29 anos só em Belém, capital de pouco mais de 2 milhões de habitantes. Belém é a $6^{\text {a }}$ capital com maior taxa de homicídios do Brasil. ${ }^{6}$ São inúmeras chacinas na capital do Pará, muitas com comprovações e indícios da participação de policiais civis e militares.

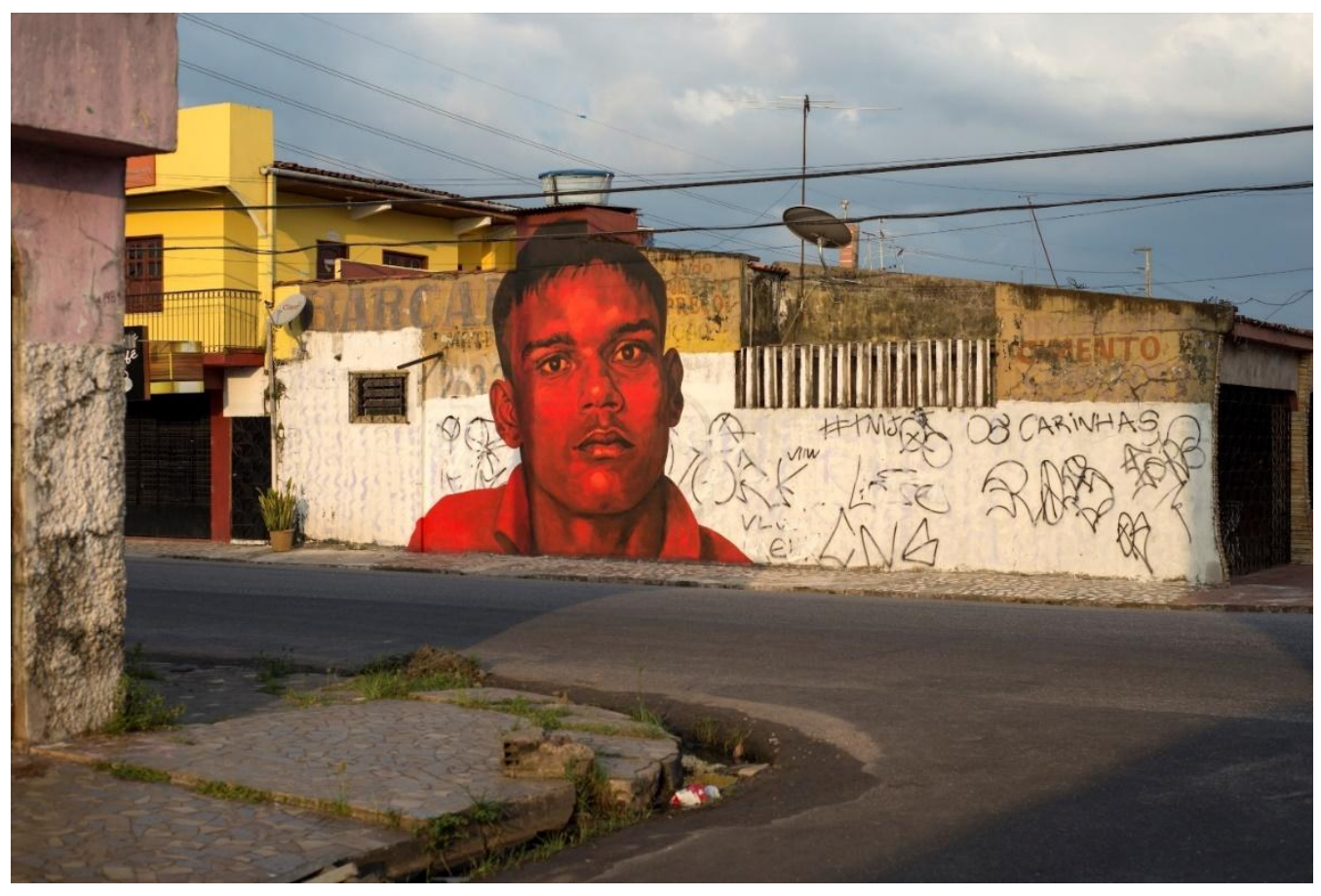

Figura 1: Anônimo, 2015. OLIVEIRA, Éder. Técnica: Intervenção Urbana. Ananindeua/PA. Imagem gentilmente cedida pelo artista.

\footnotetext{
${ }^{5}$ WAISELFISZ, Julio Jacob. Mapa da violência 2014: Os jovens do Brasil. Rio de Janeiro:CEBELAFLACSO, 2014. Disponível em:

http://www.mapadaviolencia.org.br/pdf2014/Mapa2014_JovensBrasil_Preliminar.pdf. Acesso em: 28 nov. 2014.

${ }^{6}$ Esses são os dados do Atlas da violência 2016 publicado em março daquele mesmo ano pelo Instituto de Pesquisa Econômica Aplicada (IPEA).
}

Iluminuras, Porto Alegre, v. 22, n. 56, p. 152-179, junho, 2021. 
A potência do trabalho de Oliveira com intervenções de até seis metros de altura nos muros do centro e periferias de Belém se revela na quebra das imagens estereotipadas que vemos dos jovens negros, dos corpos racializados. Quanto aos modelos que o artista utiliza, Oliveira discorre:

Meu retrato partiu dessa imagem que não presenciei, de um modelo que nunca conheci e provavelmente nunca conhecerei, de uma fisionomia que provavelmente não representava quem era o indivíduo e que ao transformar em pintura, com escala e cor alteradas e com massas e volumes sujeitas a minha interpretação, se distanciava cada vez mais deste, à medida que se aproximava do novo ser apresentado ao observador, como um retrato representativo de um coletivo. (Oliveira, 2016: 27)

As grandes proporções de suas pinturas em tons vibrantes dificilmente passam despercebidas pelos transeuntes. Da mesma forma que a imagem foi essencial para o processo de colonização, ela também será para a descolonização do imaginário brasileiro de referência sobre estes corpos.

A partir de uma perspectiva decolonial ${ }^{7}$, procuramos analisar como o trabalho de Éder Oliveira pode se colocar como uma "reviravolta de saber" (Foucault, 2005) ou uma potente contra-narrativa para um desatar de nós das rígidas e hierarquizadas relações coloniais que perduram até hoje, principalmente na violência racista e genocida que tem como alvo os corpos ainda marcados pelo processo colonial. Desse ponto de vista, almejamos mostrar como a exposição desses corpos, através do apurado olhar artístico de Oliveira, nos abre múltiplas possibilidades de pensar a descolonização desses corpos não só por meio do resgate das narrativas históricas e de saber que portam (com seus modos de ser e existir silenciados e estigmatizados enquanto inferiores e perigosos pelo pode/saber hegemônico/ocidental), como também formas de (r)existência frente às diversas formas de apagamento social impostas pelas estratégias coloniais ancoradas no racismo.

\footnotetext{
${ }^{7}$ A perspectiva decolonial é trabalhada neste texto a partir da ideia de "colonialidade do poder" proposta por Anibal Quijano, o qual destaca a permanência das relações sociais hierárquicas de exploração e dominação construídas pelas relações coloniais dos séculos anteriores. Por isso, Anibal Quijano vai identificar uma dependência histórico-estrutural, em que o processo que culminou com a independência dos Estados na América Latina não foi acompanhado de uma descolonização da sociedade, incluindo aí suas relações de poder hierárquicas sustentadas na dominação colonial/racial, mas de uma "rearticulação da colonialidade do poder sobre novas bases institucionais". A proposta decolonial seria então uma narrativa de desconstrução tanto do ponto de vista político quanto do ponto de vista epistêmico dessas relações de dominação em que etnias e saberes foram subalternizados. Ver: QUIJANO, Anibal. Colonialidade do poder, Eurocentrismo e América Latina. A colonialidade do saber: eurocentrismo e ciências sociais. Perspectivas latino-americanas. Consejo Latinoamericano de Ciencias Sociales. Buenos Aires, 2005.
} 
Nesse sentido, pensamos então no fundamental papel das pinturas de Oliveira na reconstrução da multiplicidade dos modos de ser e viver desses corpos racializados, mas também na inversão do sinal da equação, tratando esses corpos não mais como objetos de violências e perigos, mas como potência e resistência ${ }^{8}$ contra essas mesmas violências e todas as formas de apagamento físico e simbólico tão presentes na realidade brasileira.

Para a elaboração deste artigo foi feita uma revisão de literatura focada na crítica social decolonial em conjunto com catálogos ${ }^{9}$ em que o artista é citado, bem como entrevistas com o pintor ${ }^{10}$. Busca-se compreender os efeitos da colonialidade nos corpos racializados pelo processo colonial e as problemáticas decorrentes na construção "da subalterização, da invisibilidade, da desvalorização, da negação e, no limite, do rechaço ao outro, ao nãoeurocêntrico" (Alcântara, 2018). O reconhecimento a partir de uma crítica decolonial da arte pode contribuir para a mudança nas relações de racismo, para a ampliação do pertencimento cultural e para entender processos artísticos de outras maneiras.

Essa pesquisa se iniciou em virtude do IX Fórum Bienal de Pesquisa em Arte ${ }^{11}$, a qual foi apresentada na subcategoria "Teorias e Interfaces Epistêmicas em Artes" e desenvolvida no presente artigo. O primeiro subcapítulo trata do corpo racializado e da dominação colonial, a fim de contextualizar a obra e a perspectiva de Éder Oliveira. Em

\footnotetext{
${ }^{8} \mathrm{O}$ termo "resistência" não é concebido aqui por meio de uma visão que restringe a arte e as práticas de resistência na lógica de mera oposição às forças de um poder, tornado central. "Quem cria, resiste e, nesta direção, criação é movimento constante de concepções, conceitos, modos de vida." LACAZ, A. S., LIMA, S. M., \& HECKERT, A. L. C. Juventudes periféricas: arte e resistências no contemporâneo. Psicologia \& Sociedade, 27(1), pp. 58-67, 2005, p. 60.

${ }^{9}$ Os catálogos consultados para melhor percepção do trabalho desenvolvido por Éder Oliveira foram: AMAZÔNIA, A ARTE. Curadoria Orlando Maneschy. Consultoria Paulo Herkenhoff. Rio de Janeiro: Imago, 2010; AMAZÔNIA LUGAR DA EXPERIÊNCIA. Processos artísticos na região Norte dentro da Coleção Amazoniana de Arte da UFPA. Org. Orlando Maneschy. Ministério da Cultura e Petrobrás. Ed. UFPA. 2013; ARTE PARÁ 2006. $25^{\mathrm{a}}$ edição. Fundação Romulo Maiorana. Belém - PA. 2006; ARTE PARÁ 2007. $26^{\mathrm{a}}$ edição. Fundação Romulo Maiorana. Belém - PA. 2007; ARTREVIEW. Sweetheart-maker. Vol 66. No 6. Setembro, 2014; POROROCA: A AMAZÔNIA NO MAR. Curadoria de Paulo Herkenhoff. Rio de Janeiro. Editora Circuito: Museu de Arte do Rio, 2014; PRÊMIO PIPA. 2017; RETRATOS CONTEMPORÂNEOS. Organização de Éder Oliveira. Belém: Escriba, 2016; ZUM. Revista de fotografia. Instituto Moreira Salles. Vol 15. 2018. Porém, foi feito um recorte a fim de se aprofundar principalmente nas intervenções urbanas do artista, descartando ações institucionalizadas em museus.

${ }^{10}$ Os autores estavam presentes nas seguintes falas feitas pelo pintor, das quais absorveram impressões que estão presentes no texto de forma indireta: EXPERIÊNCIA VERTIGEM. Visita + Bate Papo com artistas. Realizado no museu da UFPA em 06/04/2019; CONFLUIR. Encontro com Artistas. Realizado na Casa das Artes em 09/04/2019; PROJETO ENCONTRO NA CASA. Realizado na Casa das Onze Janelas em 13/11/2019. Todos os eventos citados ocorreram em Belém do Pará. Além dos eventos assistidos, houve conversas informais com o pintor que estava ciente do trabalho que vinha sendo desenvolvido.

${ }^{11}$ Evento realizado na Casa das Artes em Belém do Pará nos dias 17 e 18 de dezembro de 2019.
} 
seguida aprofundamos as reflexões sobre a decolonialidade apresentada nas pinturas do artista. E por fim, relacionamos a obra artística de Oliveira principalmente com a obra literária e acadêmica de Frantz Fanon com o intuito de dialogá-las frente à dimensão estrutural da violência colonial.

\section{O corpo racializado sob a dominação colonial}

A história brasileira, assim como a história ocidental, escrita e registrada a partir de relações de poder-saber ${ }^{12}$ foi sendo ensinada e repetida apenas pela perspectiva do colonizador. O aprendizado do "descobrimento" do Brasil nas escolas silencia a trajetória dos corpos negros e indígenas e sua história na construção de nosso passado colonial. Os corpos que foram subjugados e colocados de maneira periférica em tantas esferas da sociedade - geográfica, política e jurídica, para citar algumas, - continuam a ser olhados com desprezo e violência pelas instituições montadas e oficializadas a partir da visão etnocentrista europeia. O aparato de dominação que se estruturou com o processo "civilizatório" europeu, o qual hierarquizou a partir da perspectiva racial as relações de saber e de cultura (Schwarcz, 1996), continua marcando profundamente as relações sociais.

O conceito de racismo, justificado como o grande motivo das hierarquizações brasileiras, teve sua criação na Europa no século XVIII na crise da Revolução Francesa. Era necessário um motivo que fundamentasse que os nobres eram destinados aos cargos de poder. Portanto, a classificação das raças foi instrumentalizada pelo imperialismo dominando o cenário intelectual no século XIX com as teorias evolucionistas. Era situado na biologia e na raça, relações que eram puramente políticas e econômicas. Isto legitimava a supremacia dos povos da Europa Ocidental sobre o resto do mundo, assim como da elite intelectual brasileira (DaMatta, 1981).

Todavia, é imprescindível problematizar o racismo para além dos "pressupostos do senso comum e formas cotidianas de falar de raça e de produzir sentido sobre raça na sociedade de hoje" (Hall, 1995). E isso, segundo Stuart Hall (1995), requer que se leve em

\footnotetext{
${ }^{12}$ Michel Foucault talvez tenha sido um dos filósofos do século XX que mais tenha se debruçado sobre essas relações que hierarquizam corpos e saberes através de estratégias de poder. Ver: FOUCAULT, Michel. Microfísica do poder. $21^{\mathrm{a}}$. ed. Edições. graal, editora: Paz e Terra, São Paulo: Edições Graal, Paz e Terra, 2005.
} 
consideração que "raça é uma construção discursiva, um significante deslizante", ou seja, que raça é conceito fundamental na organização e estruturação dos grandes sistemas classificatórios da diferença que operam em sociedades humanas. Nesse sentido, tratar raça como uma categoria discursiva é reconhecer não só a insustentabilidade das tentativas de sua fundamentação pela ciência, mas principalmente o deslocamento e a substituição da definição biológica de raça pela sócio-histórica ou cultural.

Nessa perspectiva, Stuart Hall (1995) nos convida a pensar a raça como um signo, um significante, já que a cor da pele, ainda que pouco significativa em termos de diferenças biológicas, é um distintivo fundamental que dentro dos sistemas classificatórios da diferença abarca seres humanos que possuem histórias em comum, de sofrimentos com desastrosos processos históricos e com uma longa memória desses desastres. É a partir daí que podemos pensar o racismo na modernidade para além do surgimento do seu conceito no século XVIII e da teoria das raças no século XIX, conectando-o com as estratégias e ideologias que fundamentaram a escravidão e o tráfico negreiro nos processos de colonização dos séculos XV e XVI.

Achille Mbembe (2018: 13) vai nos mostrar como a raça, funcionando como categoria originária, material e fantasmática, esteve desde o século XV na origem de inúmeras catástrofes, como a denominada "espoliação organizada" (Mbembe, 2018: 13), quando homens e mulheres originários da África foram, em proveito do tráfico atlântico, transformados em "homens-objeto", "homens-mercadorias e homens moedas", decorrendo daí uma série de devastações psíquicas e incalculáveis crimes e massacres.

Mignolo (2017) defende que o racismo surgido no período colonial estabelecia uma teoria de inferioridade baseada nas diferenças de raça na qual criava uma ficção utilizada para o domínio de terras e pessoas, afirmando os colonizadores como identidade superior, expelindo os colonizados da esfera normativa. Dessa forma, sob o processo da racialização daqueles encarados como "outros", a América pode ser inventada, mapeada, apropriada e explorada.

O racismo como discurso atua desde a colonização como um dispositivo desumanizador, afastando o negro do sentido de humanidade, possibilitando mais tarde no século XIX que a inferioridade jurídica do escravismo fosse convertida ou aprofundada numa inferioridade do tipo biológica (Zaffaroni; Batista; et al., 2003: 442). O racismo como 
discurso, seja ele ligado a mentalidades seja ele ligado à técnica de governo, é um elemento imprescindível para a legitimação/justificação do extermínio. A introdução do positivismo criminológico no Brasil no século XIX foi crucial para que o racismo contra o negro ganhasse status de "discurso científico", discurso de verdade, que deu continuidade ao genocídio contra os segmentos de cor. De objeto de trabalho a objeto da ciência (Batista, 2003: 158), os negros são vistos como miasmas, símbolos máximos do medo, do atraso e da desordem.

Portanto, a lógica colonial e seu projeto de dominação se assentou na objetificação de seres humanos e na desterritorialização de seus corpos. $\mathrm{O}$ "despedaçamento cognitivo e identitário" (Simas e Rufino, 2018: 11), como parte desse processo de objetificação provocado pela escravidão, é acompanhado de um deslocamento não só geográfico desses corpos, mas também em direção a um não-lugar em termos de humanidade. É nesse sentido que o colonialismo vai se edificar em detrimento ou como negação daquilo que ele objetifica e considera como o outro: negros e indígenas. Para levar a cabo esse processo, a agenda colonial, segundo Luiz Antônio Simas e Luiz Rufino (2018), vai trabalhar na descredibilização das inúmeras formas de existência e de saber, produzindo a morte física desses corpos, através do extermínio, e a morte simbólica através do que eles irão chamar de “desvio existencial”, que contribui para a aniquilação de outros modos de ser, viver e sentir a vida.

Com o avanço do processo civilizatório europeu atrelado ao desenvolvimento das estratégias de acumulação desigual do capitalismo, os corpos brancos hierarquizaram tanto as relações de cultura quanto as relações entre os indivíduos. Tanto modos de ser e existir dos indígenas, que já habitavam o território hoje reconhecido como Brasil, quanto dos que foram trazidos a força pela diáspora do continente hoje denominado África eram inferiorizados e tratados como não-humanos. Seus saberes e conhecimentos foram diminuídos e demonizados. A percepção unilateral de que haveria uma linearidade no desenvolvimento das civilizações dada pela antropologia evolucionista cultural (Castro, 2005) trazia a ideia de que as sociedades colonizadas estariam atrasadas e deveriam ser modernizadas pela "civilização" europeia. As estruturas e formações sociais eram questionadas, assim como o comportamento e as relações dos corpos pertencentes a elas. Nas relações coloniais, ao contrário das técnicas de disciplinamento dos países europeus, os corpos racializados eram lançados naquele "moinho de gastar gente" que nos fala Darcy 
Ribeiro (1995), domesticado através da tortura e submetido às mais terríveis práticas de exploração e mortificação.

É nesse sentido que é possível olhar para o contexto brasileiro como um intenso laboratório de relações entrelaçadas por duas faces da mesma moeda: modernidade/colonialidade. Se levarmos em consideração a afirmação de Prado Júnior que “o 'sentido' da evolução brasileira [...] ainda se afirma por aquele caráter inicial da colonização" (Prado Jr., 2011: 32), veremos que a atual conjuntura resultante do "projeto modernizador" reflete sem dúvida nenhuma o caráter estrutural da violência e da miséria intrinsecamente associadas ao desenvolvimento estruturalmente desigual do capitalismo. Vemos aqui de forma nítida que o desenvolvimento do capitalismo mais sofisticado está diretamente comprometido com a miséria e as inúmeras violências que atingem negros e indígenas desde a colonização.

O autoritarismo observado na violência colonial/estatal ancorados em práticas raciais que acompanha os deslocamentos históricos do grande capital no Brasil podem ser decifrados a partir daquele olhar que, vasculhando a "torturada história latino-americana", percebeu o nosso continente como "a região das veias abertas" (Galeano, 1979) que desde a chegada dos europeus experimenta um processo que transformou tudo em capital: os homens e as riquezas, os recursos naturais e os recursos humanos, quase sempre em benefício dos países desenvolvidos. É em Marx que Eduardo Galeano (1979: 189-281) vai perceber que a cruzada de extermínio, a escravização dos povos latino-americanos e a conversão do continente africano em local de caça de escravos negros são todos feitos que marcam a era de produção capitalista.

A hierarquização ainda se mostra presente, na qual os costumes e trejeitos relacionados à cultura negra ou indígena são tratados com inferioridade em comparação aos brancos. A mestiçagem brasileira, abordada com tanto orgulho pelo aclamado "país da diversidade", é vista com bons olhos se não levarmos em consideração a sua amarga dose de violência colonial, já que sua sedimentação está diretamente ligada às práticas de estupro de mulheres escravizadas e ao racismo. Parte daquela "extraordinária plasticidade social" atribuída aos colonizadores portugueses por Sérgio Buarque de Holanda (1995), vista como uma espécie de ausência do "orgulho de raça" e que possibilitou a mistura com gente de cor e a formação de um povo de mestiços, só pode persistir ignorando a dupla objetificação da 
mulher escravizada e todas as práticas violentas que atingiam sua corporeidade.

Giralda Seyferth (1995) defende como a ideia de raça na sociedade brasileira ainda prevalece como fator explicativo das diferenças sociais, dando respaldo ideológico para atitudes discriminatórias e outras manifestações de preconceito. Estes apontamentos das diferenças ocorriam não só nas taxonomias científicas da época, mas infelizmente também nas concepções populares que classificavam prejudicialmente os corpos racializados, e que ainda se estendem.

É sobre os corpos objetos da violência do processo de colonização, que Éder Oliveira aborda sua obra. Ele retrata e dá visibilidade ao apagamento social diário destes corpos. O pintor conta que inicia seu processo artístico em Belém baseado nas fotos jornalísticas em busca de estudar retratos que fossem similares à sua imagem e de seus pares. Infelizmente, foram nas páginas policiais que encontrou tal semelhança.

Em Belém, sempre tive fascínio pela imagem do que para mim seria o outro, o homem amazônida, pessoas que além de sua história trazem em suas fisionomias e expressões traços dos povos que construíram e constroem esse lugar, mas que grosso modo nunca tiveram voz nas decisões e no espaço que atuam, pessoas como as com quem convivi a vida inteira e que aqui, onde não há espaço para todos, continuaram a ser familiares a mim. [...] Na universidade, meu deslumbre por representar esse outro, que nada tinha a ver com o retratado na história, e a paulatina consciência de que eu também fazia parte desse grupo me fez investigar essa imagem como objeto artístico e a busca por esse modelo me fez atentar para as páginas policiais, o único lugar na mídia em que esse retrato tem domínio. (Oliveira, 2014: 346) 

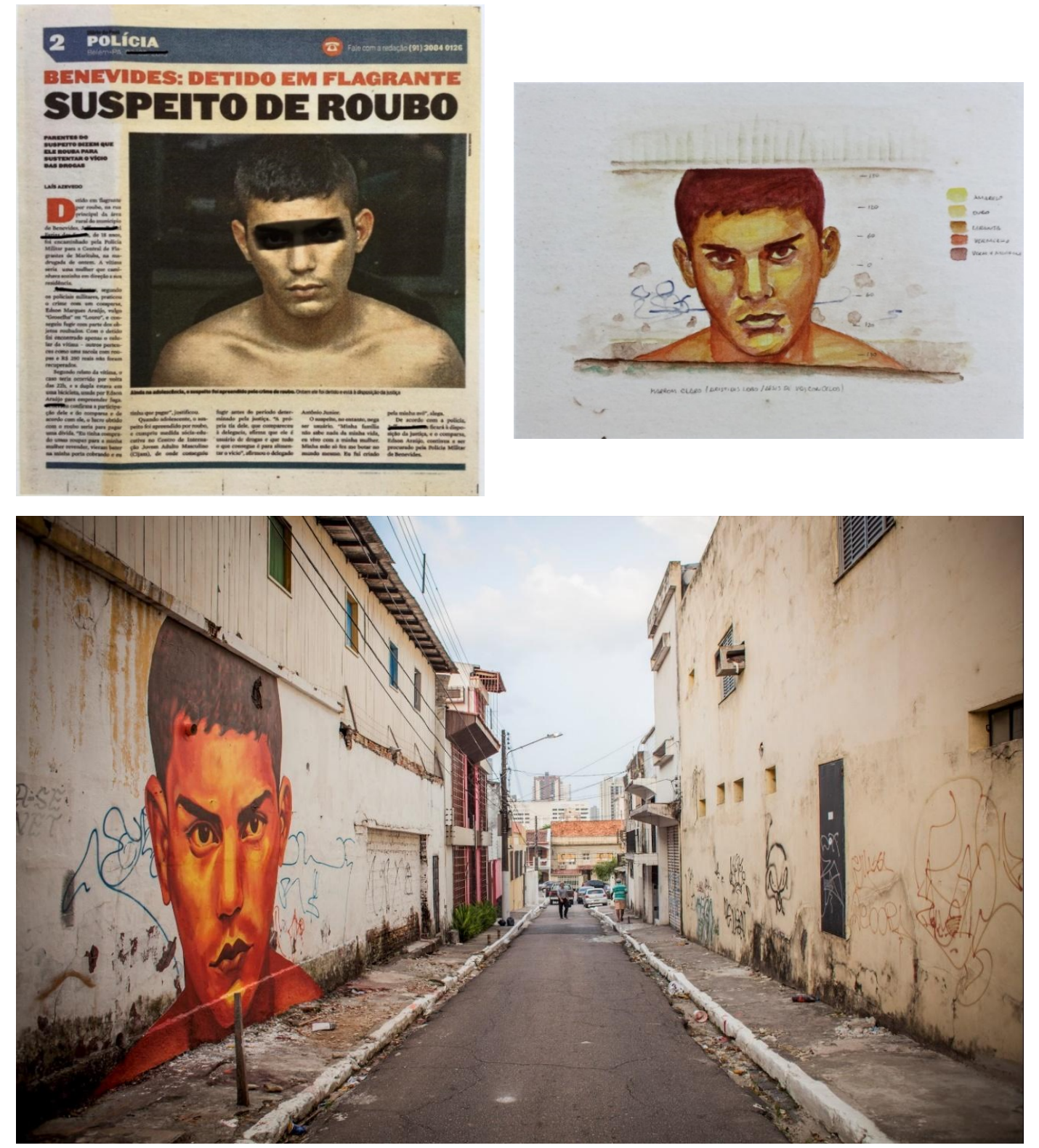

Figura 2 e 3: Processo de criação. OLIVEIRA, 2014.

Figura 4: Sem Título, 2014. OLIVEIRA, Éder. Técnica: Intervenção Urbana. Belém/PA. Foto: Ubirajara Bacelar.

Podemos contextualizar a obra de Éder Oliveira como alternativa à narrativa colonial hegemônica da história brasileira, a qual colonizou não só a forma de refletir e contar a história, mas também a forma de viver dos corpos marcados por ela. A fim de uma reflexão acerca das pinturas em que o artista espalha pela cidade de Belém do Pará, buscamos inverter o permanente olhar colonial que enquadra esses corpos como perigo no contemporâneo.

O corpo racializado nos muros pintados por Éder Oliveira 
Os corpos vistos nas obras de Oliveira têm outra forma, outra percepção que não a dos corpos objetificados vistos nas fotografias dos jornais. Pela perspectiva das pinturas frequentemente monocromáticas, o artista faz de seu daltonismo ferramenta na construção dos retratos que pinta. O artista relata: "As maçãs do rosto acentuadas, o tom de pele, a expressão marcada pelo sol equatorial e a beleza da cor que o daltonismo ora me fazia confundir com um verde sensual, ora me dizia um marrom adornado pelo suor da labuta diária, me atraíam" (Oliveira, 2014: 346).

O retrato, privilégio das elites, chega a um anônimo na sociedade, a sua pintura causa outras impressões que não a de marginalidade e perigo. A linguagem da pintura, tão reservada às classes privilegiadas, é cedida àquele que é mais negado na sociedade, o suposto infrator. $\mathrm{O}$ artista paraense abre uma fissura na estrutura, disputando espaços que antes eram reservados só por alguns, democratizando as paredes antes repletas de apenas certos padrões corpóreos. A demonstração de poder e a violência simbólica que a ausência dos corpos que são maioria em nossa sociedade causa nas imagens expostas na cidade contrasta com as obras a céu aberto de Oliveira. Alcântara (2018), defende que:

\begin{abstract}
As vozes decoloniais emergem, com efeito, não dos centros hegemônicos, mas dos limites, das periferias, "atacando" os saberes/poderes historicamente instituídos pelo longo curso de imposição colonial de que todos nós fomos e somos atores. Trata-se, de um lado, da luta pelo reconhecimento e reconfiguração geopolítica de outros saberes, outros conhecimentos e outras práticas, distanciando-se daquelas tomadas há muito tempo como verdadeiras; e, de outro, das lutas concretas direcionadas à construção de um ethos que possa ser sustentado por outras bases: pela legitimação cultural, pelo fortalecimento de uma racionalidade contra hegemônica, pela produção teórica (e, por isso, política), de narrativas crivadas pelo jugo da responsabilização. (Alcântara, 2018, online)
\end{abstract}

Oliveira conta em entrevista dada ao jornalista Oliver Basciano para a revista ArtReview que o caderno policial geralmente é a única oportunidade de ver pessoas com a sua cor de pele representadas na mídia, em um país em que mais de cinquenta por cento da população é não-branca. O artista ao mesmo tempo que representa o marginalizado no jornal, representa a ele mesmo e a tantos outros da sociedade brasileira. Éder Oliveira escancara assim a relação de poder existente na sociedade contemporânea brasileira herdada de seu passado e presente colonizador. O destino dos corpos é próprio, mas o preconceito é comunitário. Para Herkenhoff (2018) “a distopia social do problema carcerário encontra sua imagem no corpus de Éder Oliveira". 
Nos muros pintados por Oliveira, o artista provoca um olhar para o corpo que antes parecia invisível, ou que era ao menos ignorado. Para Herkenhoff (2006) "suas pinturas se tornam pequenos monumentos a anônimos, já que perdem a especificidade do crime e se tornam retrato significativo da maioria”. O pesquisador e curador Orlando Maneschy se aprofunda na crítica sobre o trabalho do paraense e desenha a consequência do encontro do público com a sua obra:

Ao pintá-los, Oliveira nos faz encarar a perversidade da sociedade e nos obriga a confrontar nossos próprios medos, nossos preconceitos, nossa insensibilidade ante o outro. Da vida para os cadernos policiais, para o mundo novamente, por meio de grandes pinturas que ressignificam e redimensionam esse cidadão antes marcado para o apagamento. (Maneschy, 2017: 62)

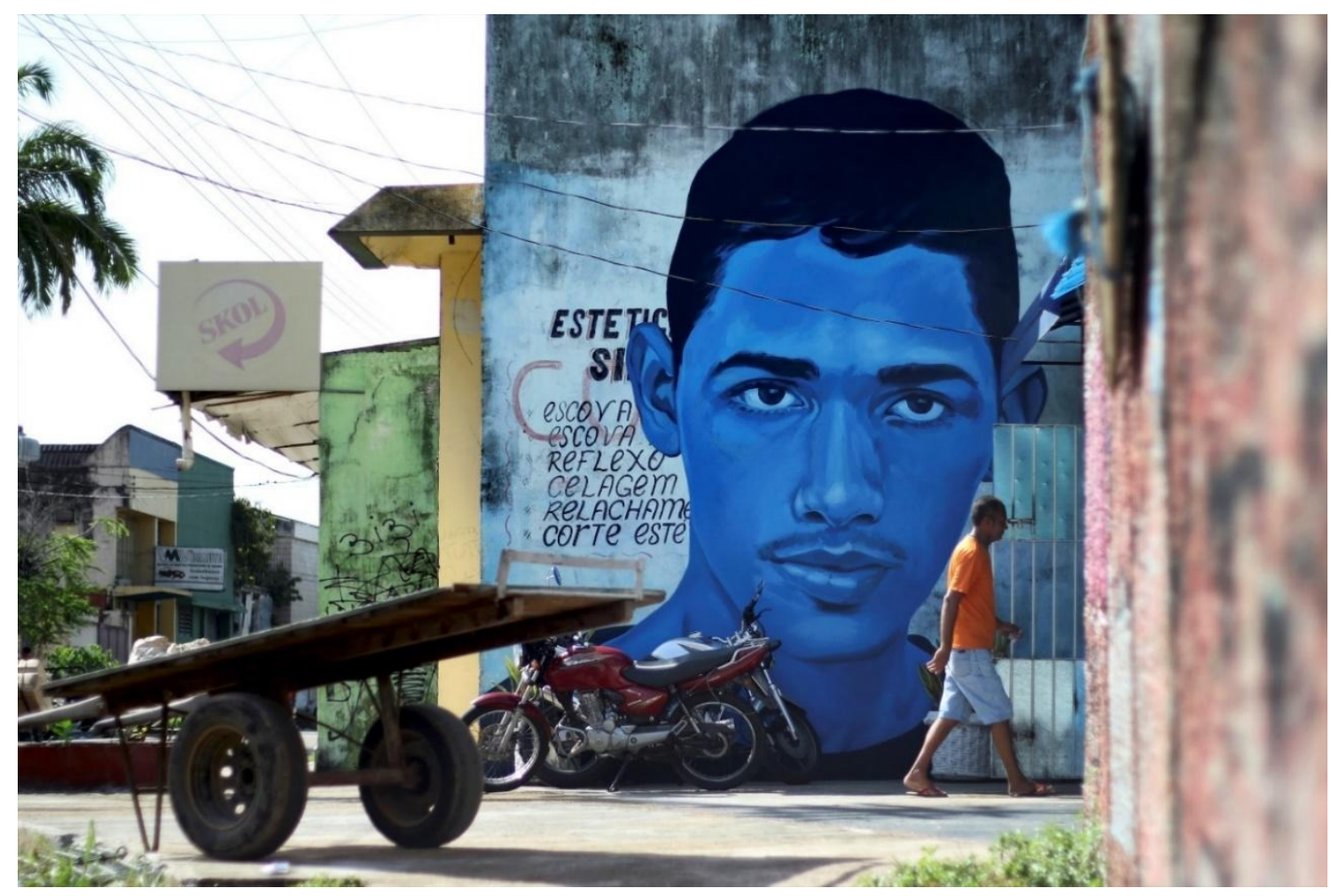

Figura 5: Sem Título, 2015. OLIVEIRA, Éder. Técnica: Intervenção Urbana. Belém/PA. Foto: Marcelo Lelis.

O trabalho artístico de Oliveira nos convoca a olhar para estes corpos para além das páginas policiais, mas também como modos de ser e existir singulares, que, através do que Adriana Facina (2014) observa como "cultura da sobrevivência”, driblam o instituído e as diversas formas de controle social, criando e ressignificando diversas formas de saberes e manifestações culturais criativas e potentes. 
Para Maldonado-Torres (2017) a pauta da re-existência se impõe em um calendário decolonial como tema crucial a confrontar a modernidade. A negação da existência de sujeitos que foram considerados primitivos ou selvagens por homens brancos se manifesta em violência desproporcionada na contemporaneidade, resultando na morte prematura da juventude entre outras tantas formas de violação sistemáticas. Para o autor, é necessária para além da resistência, a re-existência destes grupos que até hoje sofrem com as consequências da colonização, da escravização racial e do genocídio.

Assim, afirmar a arte como território de re-existência seria uma forma de expansão da reivindicação pela corporeidade descolonizada. Tratar a arte não apenas como expressão estética, mas também como esfera de re-existência que pode ser concebida como território da expressão corporal em todas as suas dimensões. Porém essa ação envolve necessariamente tanto a descolonização da arte como a vinculação de outras formas de descolonização (Maldonado-Torres, 2017).

Basciano ao final da entrevista relaciona o trabalho de Oliveira com o "Manifesto Antropofágico" de Oswald de Andrade, alegando que o artista "devora" a mídia e utiliza o retrato clássico para uso político. Para Basciano, a arte do Norte se caracteriza pela oposição às normas estabelecidas da narrativa cultural dominante - a opressão, a influência européia, o legado do modernismo e as potências artísticas brasileiras de São Paulo e Rio de Janeiro. Assim, o jornalista conclui que o paraense "não ignora essas linhagens, mas as devora e as cospe para fora" (Basciano, 2014: 119).

O trabalho de Oliveira nos leva a um ponto de reflexão sobre os racismos e elitismos da sociedade brasileira e suas enormes contradições. O meio em que utiliza para que cheguemos a elas também possui seus paradoxos. Apesar de sua perspectiva decolonial, o artista se utiliza da pintura, uma arte reconhecida desde a era do Renascimento, onde apenas aqueles considerados de grande habilidade pela elite burguesa tinham sucesso com uma estética voltada aos gostos europeus.

Tratando especificamente sobre o homem amazônida, busco lançar luzes sobre um povo específico, marginalizado e invisibilizado. Neste sentido, o retrato, outrora signo de poder, não busca inverter valores sociais, mas ressignificar a própria percepção sobre o outro, ora intervindo sobre a cidade e impondo uma imagem notoriamente rejeitada a um público transeunte ou, criando mecanismos em pintura sobre tela ou nas paredes das galerias para mostrar a um público específico a reflexão sobre essas imagens. (Oliveira, 2016: 27)

Diante disso, Oliveira utiliza de um meio legitimado para abordar a não legitimidade dos corpos marginalizados. O paraense alega: "me propus a reproduzir esses rostos em 
pintura criando um novo retrato, de alguém que provavelmente não queria o ter e para quem de outra forma normalmente não queria o ver" (OLIVEIRA, 2016: 27). Ainda, sendo artista participativo do mercado da arte contemporânea, suas telas quando compradas são apenas acessíveis para uma camada privilegiada da sociedade. A arte de Oliveira, com exceção das intervenções em muros, termina em uma sala da área nobre da cidade, área em que esses corpos raramente circulam.

Geralmente a presença destes corpos nos bairros nobres das cidades brasileiras é reconhecida em situações de prestação de serviços naquela região, e vistas com desconfiança pela vizinhança. Pacheco de Oliveira (2014) alega que a predominância dos traços racializados historicamente de indígenas, caboclos, negros, mostram uma constante dos corpos que são detidos em sua movimentação pelas ruas na realidade brasileira. As autoridades colocam em ações práticas um sistemático genocídio de pessoas que possam de algum modo ser tidas como ameaçadoras ou inconvenientes, sobretudo se pertencentes a grupos desfavorecidos na escala social. O antropólogo aponta que a prioridade sempre foi a segurança física e patrimonial das elites (neo)coloniais e quem as representam ainda atualmente. Estas práticas apenas se sustentam por uma forma corrosiva e letal de racismo que persiste.

A naturalização do aprisionamento e morte de grupos determinados é fundada em crenças racistas que homogeneizam a população periférica como uma só: periculosa e infratora. A mídia fortalece tal imaginário com representações estereotipadas dos corpos racializados. Pacheco de Oliveira (2014), comenta a abordagem policial carioca sobre estes grupos:

Na impossibilidade de demonstrá-las, a detenção (ou não) torna-se objeto exclusivamente de uma avaliação - bastante circunstancial e subjetiva - do policial. Em função de este estar exercendo uma condição extrema de poder, a única postura adequada para aquele que é posto na posição de subalterno é instaurar com ele uma relação de aparente obediência e passividade, da qual está obviamente excluída a hipótese de tentar fazer valerem os seus próprios direitos. $\mathrm{O}$ preço de um questionamento é muito alto e a reiteração do arbítrio transforma-se no caminho para a inculcação forçada de uma condição inferior, no limite, imputada como quase criminosa, num verdadeiro ritual de naturalização de uma subcidadania. (Pacheco de Oliveira, 2014: 139)

A realização ostensiva de revistas, sobretudo de jovens racializados, tem a função de frear a livre circulação destes pelos espaços urbanos e instaurar barreiras sociais. Também a desconfiança e a hostilidade dos que residem nos bairros de classe média faz com que estes 
jovens evitem a circulação por determinados espaços urbanos e acabem por ter uma experiência muito limitada e setorizada de várias áreas de sua própria cidade (Pacheco de Oliveira, 2014).

Estes mesmos corpos que frequentemente são coagidos em seus trajetos pela cidade por abordagens policiais, são equivalentes aos pintados por Éder Oliveira. Porém, uma vez que este rosto vai para a tela e ganha o status de arte contemporânea institucionalizada, a sua percepção e recepção nos bairros nobres é exaltada. A circulação livre que não pode ser vivida pelos corpos marginalizados é permitida desde que esteja estaticamente representada em uma obra de arte.

Retirar a imagem desse contexto comum a ela e transpor em pintura com o enquadramento próximo ao rosto, sem algemas, sem circunstâncias, falando de questões humanas e do que isso pode mostrar alheio a uma manchete sensacionalista é o que busco quando reproduzo o retrato do homem amazônico nas paredes da cidade de Belém, impondo ao transeunte o confronto com rostos que ele tende a ignorar, uma imagem que migrou da representação icônica do trabalho para o reflexo daquilo que se deve temer e evitar (Oliveira, 2014: 346).

Diante deste paradoxo, são as intervenções urbanas realizadas por Oliveira que levam estes corpos agigantados de cores vibrantes e com traços marcados pelo processo de racialização colonial para ruas da cidade. Saindo das exposições reservadas às elites, o trabalho do paraense ganha nova potência de significações ao se colocar na rua em contato direto com os transeuntes. Encarar a obra de Oliveira é se deparar com as permanentes injustiças sociais decorrentes do racismo estrutural brasileiro. A importância de seu trabalho se realiza em sua potência de dar visibilidade a estes corpos e narrativas marginalizadas e que têm sua existência plena negada pelo Estado.

O Estado, muitas vezes indiferente a estes corpos em suas necessidades e demandas sociais, apenas se torna presente na consequência da sua própria ausência na trajetória destas vidas. Assim, o aparato do Estado cobra uma conduta discrepante ao que foi oferecido na formação do comportamento do indivíduo periférico. Marginaliza o querer, o saber e a vivência do corpo racializado, para depois encarcerá-lo por sua ação reprovada em um acordo social feito pela branquitude. Oliveira problematiza em suas pinturas este corpo colocado enquanto marginal por quem tem a centralidade do poder. Sob esta perspectiva marcante do trabalho do artista, a curadora chilena radicada no Brasil Daniela Labra comenta: 
O artista se esmera na fatura de seus trabalhos para representar o "caboclo" - esse coletivo de excluídos sociais cujo futuro foi usurpado pelo Estado - em toda sua complexidade. [...] Suas pinturas não apontam culpados, mas humanizam rostos destinados a virar estatísticas e, quiçá, uma foto descartável (Labra, 2018).

Os corpos racializados pela lógica colonial parecem estar à mercê da estrutura do Estado e de sua ação ainda na contemporaneidade, o qual difere os indivíduos por cor, mudando o tratamento a depender do fenótipo. Aprendemos com Frantz Fanon que o preto é atingido na sua corporeidade ou é na corporalidade que se atinge ele. Para o filósofo africano martinicano o preto é linchado e malvisto enquanto personalidade concreta, e "é como ser atual que ele é perigoso" (Fanon, 1968: 142). Podemos estender o conceito de Fanon também para os corpos afro-indígenas, que são tão recorrentes na Amazônia no trabalho de Oliveira.

Enquanto permanecermos amarrados em relações decorrentes do colonialismo, que hierarquizam e inferiorizam saberes e corpos, enquanto a violência estruturada no racismo viva até hoje nas estratégias de genocídio da população afro-indígena, trabalhos como de Éder Oliveira são imprescindíveis. Isso porque sua produção artística nos força a problematizar não só a estruturalidade do racismo em nossas relações sociais, mas também aquilo que o crítico literário Robert Schwarz (2014), a partir da análise da obra de Machado de Assis, chamou de "sentido histórico da crueldade", que mostra uma formação social insensível à brutalidade das violências que estão estampadas em nossos rostos, corpos e realidades. A obra do artista paraense traz reflexões acerca destas marcas carregadas pelos olhares de suas pinturas.

\section{A potência das pinturas frente à dimensão estrutural da violência colonial}

Assim como a controversa e pouco compreendida crítica de Fanon ao colonialismo em "Condenados da Terra" (Fanon, 1968), o trabalho artístico de Éder Oliveira não deixa de causar no mínimo estranhamentos ao olhar pautado em uma perspectiva estética colonialista, em que o corpo não-branco e suas diversas expressões estão presos em lugares delimitados por fronteiras ou se encontram em uma espécie de não-lugar dentro das formas de vida aceitas pelo ocidente.

Ao ultrapassar essas fronteiras e provocar fissuras nesses (não)lugares reservados ao corpo negro, o artista abre um paralelo com as reflexões de Fanon (2008) para 
problematizações que vão não só atingir aspectos relacionados ao concebível como belo em termos de arte, mas principalmente para aspectos psico-afetivos do racismo estrutural que constitui o colonialismo, já que seu trabalho instiga pessoas negras a questionarem sua existência reduzida na realidade colonial, bem como o sentimento de inferioridade introjetado na consciência das pessoas de pele escura.

Invertendo esses não-lugares, é possível a partir do trabalho do artista paraense questionar, como fez Fanon, se o homem negro só poderia existir na presença do homem branco, como também, diante dessa perspectiva, a caracterização do negro como irracional e sem moralidade e valores éticos, propenso ao crime, tendo suas crenças religiosas associadas com o mal e sendo desprovido de história antes da colonização (Fanon, 2008).

A perspectiva de Éder Oliveira em expor os corpos racializados - que através do uso da (contra)violência e do uso de seus movimentos corpóreos de alguma forma resistiram à opressão racista das estratégias coloniais largamente presentes na atuação das agências do sistema de justiça criminal em contextos periféricos, como o brasileiro - também nos força a pensar que para Fanon é na maioria das vezes a violência e o movimento de insurreição do corpo a única válvula de escape que o colonizado tem para resistir às fronteiras rígidas impostas pelo colonialismo.

Os "corpos orgulhosos" e o olhar afrontoso de jovens negros, muitas vezes representados por Éder Oliveira, não deixa de ser uma forma de confronto e uma espécie de dobra na realidade mortífera a que estão submetidos no contexto tardio colonial brasileiro, podendo ser interpretada como uma espécie de representação atual da violência empreendida no bojo da dominação colonial. Porém, o imaginário pautado no racismo sempre buscou interpretar esses corpos orgulhosos e esse olhar altivo da juventude negra brasileira não pelo seu aspecto de denúncia às opressões de uma realidade estruturalmente violenta, mas pelas lentes criminas e do periculosismo, deduzindo sempre o caráter negativo dessa parcela da população não se rebaixar ao lugar de submissão e objeto de violência reservado ao corpo negro na estrutura social brasileira.

Por expor pessoas que supostamente são autores de delitos, poderíamos, numa limitada visão moralista e deturpada em torno da seletividade racista do sistema penal brasileiro, que cinicamente é um dos principais reprodutores da violência estrutural, reduzir e enquadrar o trabalho de Oliveira a uma forma de exaltação da violência, como em parte foi 
estigmatizado o trabalho de Fanon, quando, ao contrário, ele vem proporcionar uma contundente crítica à opressão e violência do colonialismo que só pode ser confrontada com uma violência anti-colonial (Vilela, 2018).

É aqui que podemos ver algo parecido com o que Ana Laura Silva Vilela (2018) chama atenção na reflexão feita em torno do documentário "Concerning Violence", baseado no trabalho de Fanon. Para ela, o filme inspirado na proposta de Fanon possibilita notar a violência em paisagens naturalizadas do cotidiano, chamando a atenção não para a violência que os colonizados mobilizam contra o colonizador, mas para os processos de violência assentados na dominação colonial. Para ela, “(...) na esteira do que o pedagogo brasileiro Paulo Freire identificou - ele mesmo um leitor influenciado por Fanon, há perigo em olhar apenas pela violência dos oprimidos sem perguntar quem iniciou o processo violento" (Vilela, 2018: 2020).

As imagens de Oliveira são capazes de produzir essa instigante ambiguidade que a arte tem a capacidade de nos proporcionar, pois ao mesmo tempo que nos afronta com uma imagem cotidianamente associada à violência e ao "crime" daqueles que procuramos manter longe de nossa visão e que nos é apresentado naturalmente sempre como protagonistas da violência urbana, nos constrange a pensar e a indagar antes de mais nada sobre a violência mortífera que tem como alvo essa mesma juventude, trazendo à tona a dimensão estrutural da violência e toda uma realidade de exclusão social desses jovens na realidade das periferias de Belém do Pará e da maioria das grandes cidades brasileiras.

Como observa Morais (2015), entre a realidade que choca - em que a morte ronda os jovens negros - e a realidade construída pelos estigmas em torno da violência associada a essa parcela da população, as ações do Estado brasileiro, as políticas públicas para juventude e a opinião pública insistem em discutir e enfrentar essa realidade construída (a tão propagada crescente delinquência juvenil), em vez da realidade dos fatos, da qual ninguém procura se aproximar. Uma realidade em que a juventude negra sofre a todo o momento os efeitos do mundo globalizado, seja por sofrerem violências, seja por violentarem uns aos outros. Todavia, apesar de serem as principais vítimas dessa modernidade exterminadora e segregadora, e viverem uma história em que são violentados, são as violências produzidas pela juventude, muitas vezes como resistência às estratégias de dominação colonial, que ganham visibilidade. 


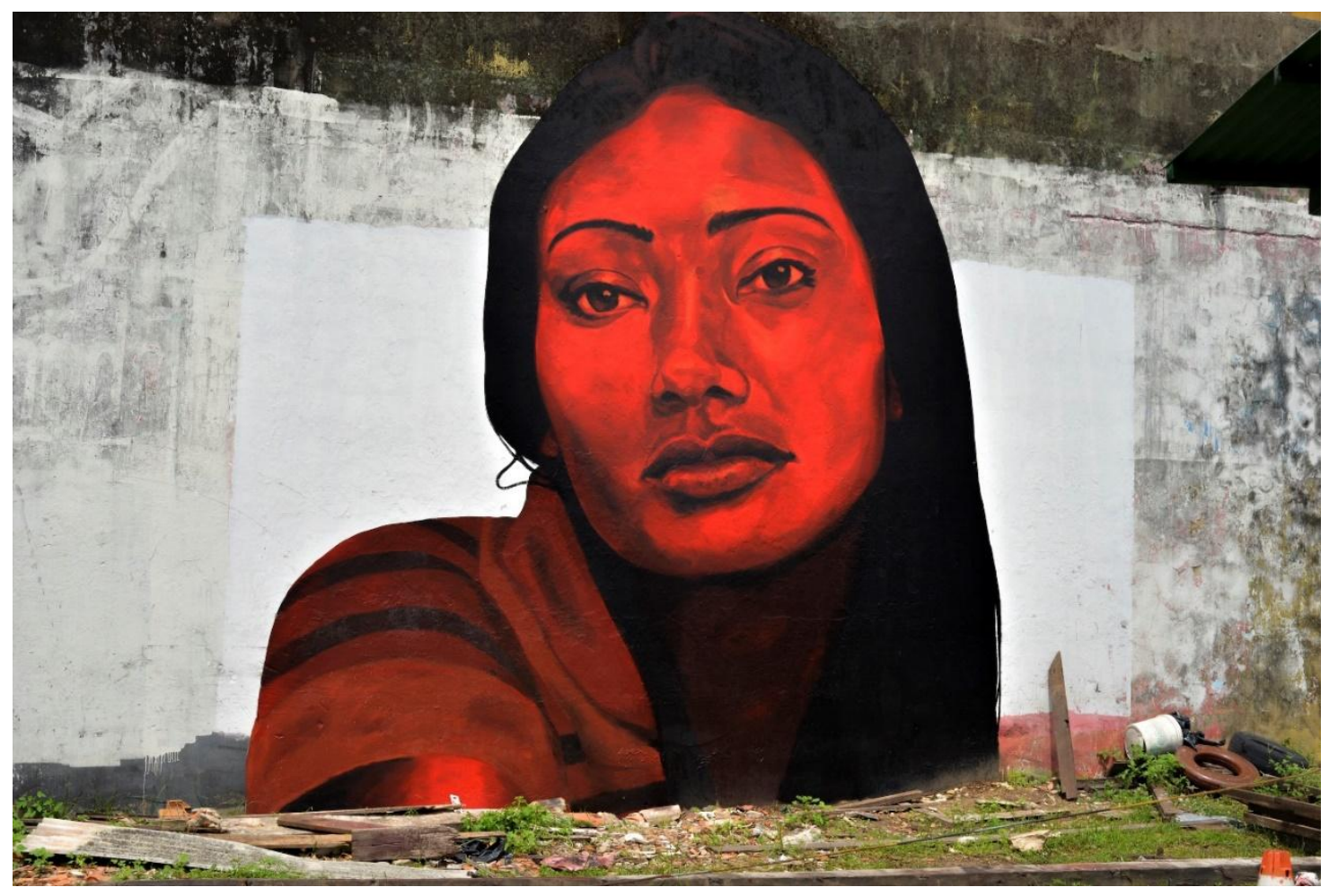

Figura 6: Sem Título, 2015. OLIVEIRA, Éder. Técnica: Intervenção Urbana. Belém/PA. Imagem gentilmente cedida pelo artista.

Aqui vemos que a arte de Oliveira contribui em grande parte com a tarefa de destrinchar a violência que presidiu ao arranjo do mundo colonial diretamente responsável pela destruição dos modos de aparência e do vestuário do colonizado. O resgate desses modos da aparência dos traços corporais não deixa de ter uma importância fundamental na destruição dos traços da lógica colonial. Mas destruir essas aparências não é simplesmente buscar um lugar ao sol ou tornar aceitável esses modos de aparência, abrindo zonas de passagem dentro do mundo colonial, mas “(...) abolir uma zona, enterrá-la profundamente no solo ou expulsá-la do território" (Fanon, 1968: 30).

Longe de uma linguagem artística que exotiza o homem amazônico, tão presente naquela típica paisagem do corpo desnudo de um ribeirinho à beira de um rio da região, a exposição do corpo vem mostrar os modos de aparência cotidiana comum desses indivíduos em seu cotidiano pela cidade, o que geralmenre entra em choque com aquele ideal de cidade colonizadora em que os corpos " [...] nunca estão à mostra, salvo talvez no mar, mas nunca ninguém está bastante próximo deles" (Fanon, 1968: 28). É o corpo e a aparência que não tem lugar no ideal de cidade aos moldes da branquitude. 
Problematizando o trabalho de Oliveira a partir dos discursos do positivismo criminológico e seu enraizamento na mentalidade e nas práticas das agências de controle social na realidade brasileira, notadamente seu viés racista que patologizou e naturalizou entre nós a ideia de crime associado à pobreza e à raça, nos deparamos com uma importante “dimensão estética” ligada às permanências de longa duração do colonialismo. Um dos aspectos dessa dimensão é analisado por Zaffaroni (2012), quando coloca em discussão a relevância adquirida pelas noções de feiúra e maldade nesse contexto. A ideia de feio, relacionada com a falta de beleza ou de valor estético, vai ser constantemente associada à ideia de maldade, no sentido de falta de valor ético, sendo os povos colonizados os genuínos portadores de tais características. É daí que a articulação dessas duas ideias vai solidificar entre nós toda uma subjetividade que automaticamente concebe o indivíduo etiquetado como "criminoso", como portador de características antiéticas e ligadas à feiúra. É assim que no contexto brasileiro toda essa dimensão estética vai ganhar rosto e corpo com o racismo estrutural, em que os indivíduos de cor serão não só associados à criminalidade, e, portanto, propensos ao crime, mas também à degenerescência, à doença, à falta de ética, à imoralidade, à sujeira, ao perigo e à noção de feio.

$\mathrm{Na}$ articulação entre falta de beleza diretamente ligada à ausência de valores forjada por essa estética racista, Fanon (1968) vai observar essas estratégias serem colocadas cotidianamente em curso e legitimarão uma série de práticas violentas no corpo e na mente dos indivíduos colonizados: “o negro é o símbolo do Mal e o do Feio. Cotidianamente, o branco coloca em ação esta lógica."

O indígena é declarado impermeável à ética, ausência de valores, como também negação dos valores. É, ousemos confessá-lo, o inimigo dos valores. Neste sentido, é o mal absoluto. Elemento corrosivo, que destrói tudo o que dele se aproxima, elemento deformador, que desfigura tudo o que se refere à estética ou à moral, depositário de forças maléficas, instrumento inconsciente e irrecuperável de forças cegas. (Fanon, 1968: 31)

É nesse sentido que a exposição do corpo negro faz com que o trabalho artístico do pintor paraense se choque com uma dupla estrutura colonial, provocando fissuras ao mesmo tempo na dimensão estética referida acima, que associa a ideia de beleza aos padrões corporais ocidentais ligados à branquitude, trazendo à tona o caráter estruturalmente racista dessa dimensão que estigmatiza o negro enquanto sujeito associado à feiúra, mas também alcança uma das grandes estratégias de dominação colonial que perdura até hoje nas práticas 
de controle social estruturalmente racista e sustentado na concepção do negro enquanto sujeito mal, perigoso, e, portanto, potencial criminoso, já que o trabalho de Oliveira também busca explorar as imagens expostas em cadernos policiais, produzindo outra narrativa para além da cotidiana imagem que tenta de todas as formas associar a juventude negra às mazelas e às mais diversas formas de violências que nos assolam.

A pintura que não busca contornar e delimitar os sinais simbólicos do indesejável, o quadro que não enquadra, o retrato que não aprisiona, mas expande e transborda fronteiras coloniais. Com a exposição do corpo racializado atravessado por dimensões estruturais da violência, como o racismo, a sensibilidade artística de Oliveira parece escancarar também uma questão fundamental da dominação colonial: a estrutura construída para a limitação da liberdade, em que os movimentos de insurreição desses corpos, muitas vezes através da violência física, são interpretados como algo negativo.

O indígena é um ser encurralado, o apartheid é apenas uma modalidade de compartimentação do mundo colonial. A primeira coisa que o indígena aprende é a ficar no seu lugar, não ultrapassar os limites. Por isso é que os sonhos do indígena são sonhos musculares, sonhos de ação, sonhos agressivos. Eu sonho que dou um salto, que nado, que corro, que subo. Sonho que estouro na gargalhada, que transponho o rio com uma pernada, que sou perseguido por bandos de veículos que não me pegam nunca. Durante a colonização, o colonizado não cessa de se libertar entre nove horas da noite e seis horas da manhã. (Fanon, 1968: 39)

É por isso, então, que o exercício da violência, ou corpos que na maioria das vezes estão ali representados dentro de um contexto de violência (criminal) na obra de Éder Oliveira, precisam ser vistos pelas lentes do pensador martinicano: "o colonizado descobre o real e transforma-o no movimento de sua práxis, no exercício da violência, em seu projeto de libertação" (Fanon, 1968: 41). A arte pode nos mostrar linhas de fuga para toda essa violência cotidiana que esses corpos protagonizam, reorientando toda sua força não para o suicídio coletivo, muitas vezes representado pelos confrontos e assassinatos de uns contra os outros, mas para a libertação.

Aqui podemos encontrar a dupla face da colonização, vista por um lado em toda a violência a que o corpo racializado é submetido pelos dispositivos coloniais, e, por outro, toda a violência que esses corpos se lançam no cotidiano como reflexo direto da “agressividade sedimentada nos músculos" (Fanon, 1968: 39) por aqueles dispositivos. Esse é o período em que os colonizados batem uns aos outros e são arrastados por uma necessidade 
de levar a cabo a libertação desses corpos como condição do processo de descolonização.

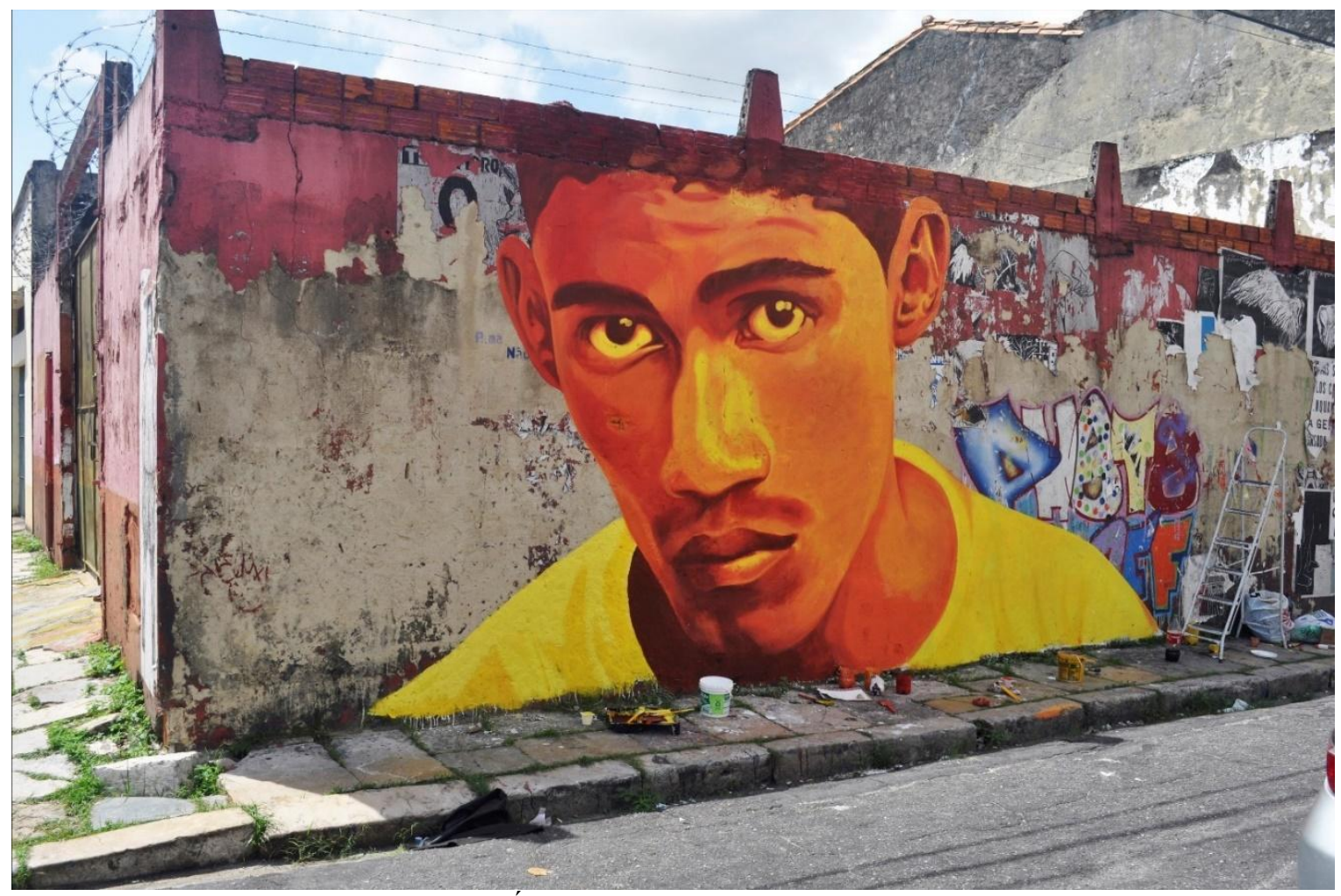

Figura 7: Sem Título, 2013. OLIVEIRA, Éder. Técnica: Intervenção Urbana. Belém/PA. Imagem gentilmente cedida pelo artista

Dentro dessa problematização, é interessante perceber o quanto os movimentos artísticos e culturais que têm como protagonistas os indivíduos de pele escura são muitas das vezes meios de canalização de impulsos corporais e sonhos musculares e de ação contidos dentro dos limites impostos pela estrutura colonial. A partir disso podemos pensar o quanto os movimentos corporais das danças, principalmente a forma de dançar do samba, passando pelo funk e o hip-hop, ao tecno-brega, poderiam estar ligados a esse processo de libertação do corpo negro, seus sonhos de liberdade corpórea, torcendo as fronteiras dos modos de existir que buscam sugar sua potência.

Em outro plano veremos a afetividade do colonizado esgotar-se em danças mais ou menos extáticas. Por isso é que um estudo do mundo colonial deve obrigatoriamente aplicar-se à compreensão do fenômeno da dança e da possessão. A relaxação do colonizado consiste precisamente nessa orgia muscular, no curso da qual a agressividade mais aguda, a violência da mais imediata são canalizadas, transformadas, escamoteadas. $\mathrm{O}$ círculo da dança é um círculo permissivo. Protege e autoriza. Em horas fixas, em datas fixas, homens e mulheres reúnem-se num determinado local e, sob o olhar grave da tribo, entregam-se a uma pantomima de aparência desordenada, mas na realidade bastante sistematizada em 
que, pelos variados meios - negativas feitas com a cabeça, curvatura da coluna vertebral, recuo apressado de todo o corpo - expõe-se desde logo o esforço grandioso de uma coletividade para se exorcizar, para se libertar, para se exprimir. Tudo é permitido no círculo. O morro onde se erguem como que para ficarem mais próximos da lua, a ribanceira por onde se deixam escorregar como que para manifestarem a equivalência da dança e da ablução, do banho, da purificação, são lugares sagrados. Tudo é permitido porque, na realidade, só se reúnem para deixar que a libido acumulada e a agressividade reprimida extravasem vulcanicamente. Execuções simbólicas, cavalgadas figurativas, chacinas múltiplas e imaginárias - é necessário que tudo isso transborde. Os maus humores escoam-se, estrepitosos como torrentes de lava. (Fanon, 1968: 43)

Tais expressões, então, podem nos dizer muito sobre todo o processo de dominação colonial a que esses corpos são submetidos, tanto nos seus modos de aparência quanto nos seus movimentos corporais.

A exposição do corpo negro por Oliveira não deixa de problematizar todas essas questões não só animalescas que naturalizaram o lugar desse corpo na estrutura social construída a partir do racismo e da dominação colonial, como também contribuir para a descolonização de todas essas maneiras de ver o corpo no espaço e nesse lugar historicamente construído, trazendo para o campo da resistência e da denúncia todo esse processo.

Ao contrário das imagéticas cordiais e estáticas de boa parte das representações artísticas de diversos campos da arte, idealizando e exotizando um certo perfil do colonizado, do sujeito periférico, os retratos de Oliveira expõem um corpo em ato, em ação, em potência, um perfil afrontoso mesmo diante de uma realidade tão desoladora de carências materiais.

\section{Conclusões}

A arte pode despertar o olhar e os sentidos até dos mais desavisados, até dos menos atentos. Não é necessário querer questionar-se para que os questionamentos surjam em nossos pensamentos. Não controlamos o que a arte nos indaga, no que ela nos inspira, no que ela nos incomoda. As pinturas de Éder Oliveira nos muros podem ser interpretadas de diversas formas pelos olhares que as atravessam. Oliveira faz com que da mesma forma que estranhemos aqueles rostos gigantescos, com cores que pouco tem a ver com a cor humana, nos reconheçamos no olhar do outro, na expressão do outro, na postura do outro. Por meio da semelhança e da alteridade, Oliveira chega a nós para reumanizar o desumanizado. E nos deixa nus frente aos nossos preconceitos, encarando as raízes da colonização que ainda amarram nossas razões e juízos. Enxergar estes corpos a partir do olhar do artista paraense, 
que mesmo daltônico percebe com sensibilidade as nuances das cores das peles brasileiras, é uma forma de descolonização de si mesmo.

Dessa forma, olhado a partir de uma perspectiva decolonial, o trabalho de Éder Oliveira nos abre múltiplas possibilidades de pensar não só o resgate das narrativas históricas, corpos e modos de ser e existir silenciados e estigmatizados enquanto inferiores e nãohumanos, como também formas de resistência frente às diversas formas de apagamento social impostas pelas estratégias coloniais ancorados no racismo. Nesse sentido, pensamos então no fundamental papel das pinturas de Oliveira na reconstrução desses corpos racializados, tratando esses corpos não mais como objetos de violências e perigos, mas como potências e resistências contra essas mesmas violências e todas as formas de apagamento físico e simbólico tão presentes na realidade brasileira.

A obra de Éder Oliveira serviu como base para problematizarmos o processo colonial e suas marcas deixadas nos corpos na atualidade. $\mathrm{O}$ artista paraense abre fissuras decoloniais na colonialidade presente do cotidiano brasileiro. Assim, se faz necessário que esse debate se amplie, seja a partir da arte ou de qualquer outro modo de intervenção nas ruas, que seja acessível e possível para que se abram novas indagações sobre os usos da cidade e a descolonização de seus espaços.

\section{REFERÊNCIAS}

ALCÂNTARA, Celina Nunes. O Decolonial na pesquisa em artes no Brasil [online]. SciELO em Perspectiva: Humanas, 2018.

ANJOS, Moacir dos. Estavam bem mortos. Revista Zum - Instituto Moreira Salles. Ed. 11. Outubro de 2016.

BASCIANO, Oliver. Cultures and Vultures. They do things differently in the north east of Brazil. ArtReview. Setembro, 2014, p. 114-119.

BATISTA, Vera Malaguti. O medo na cidade do Rio de Janeiro: dois tempos de uma história. Rio de Janeiro: Revan, 2003. 
CASTRO, C. (org.). Evolucionismo Cultural. Rio de Janeiro: Zahar, 2005.

DaMATTA, Roberto. Relativizando. Petrópolis: Vozes, 1981.

FACINA, Adriana. Sobreviver e sonhar: reflexões sobre cultura e "pacificação" no Complexo do Alemão. In: Márcia Adriana Fernandes; Roberta Duboc Pedrinha. (Org.). Escritos Transdisciplinares de Criminologia, Direito e Processo Penal: homenagem aos mestres Vera Malaguti e Nilo Batista. 1ed.Rio de Janeiro: Revan, 2014, v. 1, p. 39-47.

FANON, Frantz. Os condenados da terra. Rio de Janeiro: Editora: Civilização Brasileira, 1968.

FANON, Frantz. Pele negra, máscaras brancas. Salvador: EDUFBA, 2008.

FLAUZINA, Ana Luiza Pinheiro. Corpo negro caído no chão: o sistema penal e o projeto genocida do Estado brasileiro. Dissertação (Mestrado em Direito) - Universidade de Brasília, Brasília, 2006.

FOUCAULT, Michel. Microfisica do poder. 21ª . ed.Edições. graal, editora: Paz e Terra, São Paulo: Edições Graal, Paz e Terra, 2005.

GALEANO, Eduardo. As veias abertas da América Latina. Trd. Galeano de Freitas, $8^{\mathrm{a}}$ Ed., Rio de Janeiro: Paz e Terra, 1979.

HALL, Stuart. Raça, um significado flutuante.Conferência de 1995 (Race, the Flooting Signifier). Revista do Programa Avançado de Cultura Contemporânea. Trad. Tradução de Liv Sovik, em colaboração com Katia Santos, 2017.

HERKENHOFF, Paulo. O XXV Arte Pará. Arte Pará 2006. Fundação Romulo Maiorana. 2006.

HERKENHOFF, Paulo. Éder Oliveira. Pintura - ou a fotografia como violência. Catálogo Museu KunsthalleLingen. Ed. VerlagKettler, 2018, p. 46-50. ISBN 978-3-86206-704-6 
LABRA, Daniela. Um Homem Amazônico. Revista Zum - Instituto Moreira Salles. Ed. 15. Outubro de 2018.

LACAZ, A. S., LIMA, S. M., \& HECKERT, A. L. C. Juventudes periféricas: arte e resistências no contemporâneo. Psicologia \& Sociedade, 27(1), pp. 58-67, 2005.

MALDONADO-TORRES, Nelson. El arte como territorio de re-existencia: una aproximación decolonial. Iberoamérica Social: revista-red de estudios sociales VIII, pp. 26 - 28. 2017.

MANESCHY, Orlando. Em tempos difíceis a arte é a única opção contra a violência. Catálogo Prêmio PIPA 2017.

MBEMBE. Achille. O devir-negro do mundo. In Crítica da razão negra. São Paulo: N-1

Edições. 2018,

MIGNOLO, Walter. Desafios decoloniais hoje. Epistemologias do Sul. Foz do Iguaçu/PR, 1(1), Pp. 12-32, 2017.

MORAIS, Rômulo. O extermínio da juventude negra: uma análise sobre os discursos que matam. Rio de Janeiro: Revan, 2019.

OLIVEIRA, Éder. Autorretrato. In: Pororoca: A Amazônia no MAR. Rio de Janeiro. Editora Circuito: Museu de Arte do Rio, 2014.

OLIVEIRA, Éder. Retrato de quem não o queria. In: Retratos Contemporâneos. Belém: Edições do Escriba, 2016.

PACHECO DE OLIVEIRA, João. Pacificação e tutela militar na gestão de populações e territórios. Mana, Rio de Janeiro, v. 20, n. 1, p. 125-161, Apr. 2014. Disponível em: http://www.scielo.br/scielo.php?script=sci_arttext\&pid=S0104-93132014000100005 
PACHECO DE OLIVEIRA, João. Narrativas e imagens sobre povos indígenas e amazônia: uma perspectiva processual da fronteira. In: O nascimento do Brasil e outros ensaios. "Pacificação", regime tutelar e formação de alteridades. Contra Capa. Rio de Janeiro, 2016, pp 161-192.

PRADO JR., Caio. “Os sentidos da Colonização”. In. Formação do Brasil Contemporâneo. São Paulo: Companhia das Letras, 2011.

QUIJANO, Anibal. Colonialidade do poder, Eurocentrismo e América Latina. A colonialidade do saber: eurocentrismo e ciências sociais. Perspectivas latino-americanas. Consejo Latinoamericano de Ciencias Sociales. Buenos Aires, 2005.

SCHWARCZ, L. M. Usos e Abusos da Mestiçagem e da Raça no Brasil. Afro-Ásia, 18, 1996, p. 77-101.

SCHWARZ, Roberto. O sentido histórico da crueldade. In: Ideias fora do lugar: ensaios selecionados. São Paulo: Perguin Classics Companhia das Letras, 2014.

SEYFERTH, Giralda. A Invenção da Raça e o Poder Discricionário dos Estereótipos. Anuário Antropológico/93. Rio de Janeiro: Tempo Brasileiro, 1995, pp. 175-203.

VIEIRA, Elisa Martins Belém. Afinal, como a crítica decolonial pode servir às artes da cena? ILINX - Revista do LUME. N. 10. 2016.

VILELA, Ana Laura Silva. Violência Colonial e Criminologia: Um confronto a partir do documentário ConcerningViolence. Rev. DireitoPráx. 2018.

ZAFFARONI, Eugenio Raul; BATISTA, Nilo; ALAGIA, Alejandro; SLOKAR, Alejandro. Direito Penal Brasileiro I: primeiro volume - teoria geral do direito penal. Rio de Janeiro: Revan, $4^{\mathrm{a}}$ edição, 2003.

Recebido: 22/03/2021

Aprovado: 02/06/2021 